Article

\title{
Buddhism and Legislative Measures on Theft in Mongolia (The 18th Century-the Early 20th Century)
}

\author{
Vesna Wallace \\ Religious Studies, University of California, Santa Barbara, CA 93106, USA; vwallace@religion.ucsb.edu
}

Received: 22 August 2017; Accepted: 30 October 2017; Published: 1 November 2017

\begin{abstract}
This article examines the issue of theft as addressed in two legal texts-the Khalkha Regulations and the Laws and Regulations to Actually Follow-which functioned as the customary and statutory laws for Khalkha Mongolia at different periods, and which governed the life of lay and monastic Buddhists. The article approaches the concept of theft as a broader category that encompasses both the direct and indirect modes of theft that involve various types of deception and fraud, whereby a person can defraud the another of his rightful belongings. The analysis of the given topic in this paper is based on the two texts from that administered the conduct of monks and laity who belonged to the personal estate, or Great Shavi, to Jebtsundamba Khutukhtus of Mongolia, the record of actual course cases dealt by the Ministry of Great Shavi, and the Mongol Code of Law instituted by the Qing administration for its Mongolian colony. Although a comparative analysis of these laws with the minor banner laws or those instituted among Oirats may reveal some important differences, it is beyond the scope of the article and deserves a through study.
\end{abstract}

Keywords: Buddhism; theft; penal system; fines; pastoral economy; Jebtsundamba Khutukhtu; Great Shavi

The Mongolian word khulgailakh (Classical Mong. qularuqu), ${ }^{1}$ which is commonly used in the two legal texts-the Khalkha Regulations and the Laws and Regulations to Actually Follow, ${ }^{2}$ which will be discussed below-denotes "stealing", and "robbing" in the strict sense of the term. But it also implies the notion secrecy, as evidenced by its adverbial form khulgaigaar in Modern Mongolian, or qularai-bar in Classical Mongolian, which means "secretly", or "stealthily", and is derived from the closely related noun khulgai in Modern Mongolian, or qularai in Classical Mongolian ("theft", "robbery", and "thief", "robber"). Thus, one may say that any action that is surreptitiously done for the sake of misappropriating another person's possession or for economically benefiting oneself while damaging another can be regarded as theft. In the aforementioned law books, these types of deceptive acts include speculation of goods, cheating on measurements, gambling, harboring pursued thieves, bandits, and gamblers, and failure on the part of law enforcement to bring them to justice. These legal texts also provide the comprehensive systems of punishment and reward for the prevention of the mentioned crimes and for the recovery of stolen property. Similar restrictions and penal measures can be found in a variety of other legal texts issued by various religious figures associated with Ikh Khüree during the nineteenth and early twentieth centuries Mongolia, which will be taken into consideration in the future in a monograph.

A discussion of theft in the context of Mongolian Buddhism and law also necessitates at least some mention of the concept of property as traditionally understood in Mongolia. An analysis of the various customary and statutory laws that were enacted at different periods in the history of Khalkha Mongolia reveals that until the late twentieth century, private property (amin-u ömči) consisted

\footnotetext{
1 In its various form, this word was used eighty times in The Laws and Regulations to Actually Follow.

2 Khalkha Juram and Jinkhen Yavakh Dagaj Khuuly Dürem.
} 
only of movable commodities, which were gained through inheritance (öblekü), labor (ködelmüri-yin kölïsün, olja a), compensation, or ransom (tölïgesiü) as in the case of the bride abduction or incurred damages, and through domination (ě̌emsil). In contrast, immovable property was considered communal property (neite-yin ömči) of the clan-units, larger administrative units (aimas, qošisu, otur), state, or a ruling khan. The right to land as a personal property was not recognized. Land was for common use, mainly for animal herding and hunting, and it could not be sold, purchased, or mortgaged. ${ }^{3}$ The same law applied to Buddhist monastic buildings and temples until most recently in the post-socialist Mongolia, when some newly built and renovated temples and monasteries in Mongolia have become private property of the individuals who in most cases are not fully ordained monks. The fact that discussions on theft in the earlier mentioned legal texts relate only to movable, private property indicates that the theft of immovable property did not pose a threat to the internal affairs of the traditional, nomadic society of Mongolia.

Moreover, when examining the issues of property and theft in the context of Mongolia's nomadic, pastoral society prior to the early twentieth century, whether in legal texts or in historical accounts, one predominantly encounters references to livestock and serfs, and less to money. A reason for this that nomadic societies in general tend to evaluate wealth in terms of possessions indispensable for sustaining and enhancing a nomadic, pastoral lifestyle. Mongolia had no monetary currency of its own since the middle of the fourteenth century until 1925 when Mongolian tugrig (tögrïg) came into use. During the Qing rule in Mongolia (from the latter part of 17th century until 1911), Chinese silver weight units $(\text { lan })^{4}$ functioned as money. Upon the liberation from the Qing dynasty, lan was replaced by Russian silver or paper rubles, and after 1917, Chinese silver dollar and Chinese paper currency were introduced. On account of the frequent scarcity of such money, blocks of brick-tea, ${ }^{5}$ baskets of yellow tea, sheep and livestock, various kinds of animal products, roles of silk, and the like were used as a common currency.

\section{Some Discussions on Theft in the Khalkha Regulations (Qalq-a $J$ irum)}

The first legal code that was enacted in 1709 to administer and regulate the Great Shavi (institution the oversaw Jebtsundmba's serfs) of the First Jebtsundamba Khutukhtu was called the Khalkha Regulations. This code, together with its later revisions, functioned as a code of customary laws for Khalkha Mongols and as a statutory law for the Great Shavi, ${ }^{6}$ which consisted of monastic and lay serves, until the early twentieth century. As a customary law that regulated not only religious but in most part also secular aspects of the life of Jebtsundamba Khutukhtus' serfs, it stands as an example of a secular Buddhist law in what was the exclusively Buddhist setting of Ikh Khüree and its related areas. If one were to look for effects of Buddhism on this and other legal texts discussed in this article, one will not find discussions on stealing as a violation of the second Buddhist ethical principle, preceded by killing. However, one will at times find the influences that can be straightforwardly ascribed to Buddhism or in more subtle ways, while not at other times. One also must take into consideration that the authors/compilers and editors of the Khalkha Regulations were Mongolian high Buddhist lamas and noblemen, who put together the regulations for the predominantly Buddhist society.

(Riasanovsky 1965, p. 207).

Lan (liang, tael) is a measure of weight equal to $37.3 \mathrm{~g}$.

According to the report of Jambal lama, the chaplain of Badma Yogo College of exorcism during the theocratic period in Mongolia, in his time, one brick of tea was the same as a half tea, which was equal to thirty "yellow teas." One yellow tea weighed $40 \mathrm{~g}$. Twenty-two yellow teas were equal to one silver cent. See (Bawden 1997, pp. 4-5).

6 The largest monasteries and their economic institutions belonged to the incarnations of Jebtsundamba (Tib. rJe btsun Dam pa) Khutukhtus, also known as Bogdo Gegeens ("Holy Incarnate Lamas"), who owned a personal estate, called the "Great Shavi" (Ikh Shavi). This consisted of extensive pastures, livestock, and lay (khar shavi) and monastic subjects (lam shavi), or serfs, who supported Bogdo Gegeens' monastic institutions. The institution of the Great Shavi was first established in 1640, when Zanabazar (1635-1723), who was recognized as the first Jebtsundamba Khutukhtu (an incarnation of Tāranātha), was given a donation of one hundred and eight households by Mongolian nobles. Over the course of time, the institution of the Great Shavi expanded, having 111,466 subjects in 1825 . 
In its original form this text contained seven articles and one hundred and ninety-four sections regulating all aspects of life. It regulated the prerogatives and provisions for Jebtsundamba (Rjes btsun dam pa) Khutukhtu, whom it extolled as a refuge of Mongolian people. It eulogizes him as the highest spiritual mentor, who incorporates all the Buddhas from the ten directions, and whose mind of awakening (bodi-yin sedkil) guides all things with compassion. The code also regulated the activities of government messengers and nobility, family and business relations, trade laws, conduct in the public sphere, collection of debts, disputes, criminal cases, ransom, murder, physical assaults, court decisions, penalties, and so on. Its later versions dating from 1676 and 1736 included the regulations pertaining to the monks' privilege of exemption from paying taxes and tributes, and a special statute enacted to protect monasteries' properties from theft and attack. After 1789, the Khalkha Regulations applied only to the Great Shavi, as the Qing's Mongolian code Lifan Yuan Zeli (Mongrol čaraǰin-u bičig) ${ }^{7}$ became the statutory law for other Khalkha Mongols. About forty articles of the Khalkha Regulations pertained to the theft of the herds and treasuries belonging to Jebtsundamba Khutukhtu ${ }^{8}$ and Buddhist monasteries, to theft from temples, and to theft in general. An analysis of the contents of the Khalkha Regulations reveals that this code was formulated on the basis of a pastoral economy built on a tribal, nomadic way of life. Its pastoral and nomadic character is most fully reflected in its penal system, which was predominantly based on livestock fines, most frequently counted in groups of nine-specifically, two horses, two bulls, two cows, two sheep, and one calf-and less on monetary compensations. ${ }^{9}$ The punishment for the theft of the livestock belonging to monks was a fine of twelve groups of nine head of male and fourteen groups of nine head of female livestock. The extent of punitive measures depended on the degree of theft or robbery. The Khalkha Regulations differentiated three degrees of theft-the first, second, and third degree-depending on whether the accused was the chief organizer of the theft, an accessory to it, or concealed it. However, other forms of punishment such as confiscation of property, beating ${ }^{10}$ confining, hobbling into a cangue, mutilation, compulsory labor, ${ }^{11}$ fine in serfs and family members, and compulsory supply of tea to monasteries were also implemented. In cases of theft from the herds and treasury of Jebtsundamba Khutukhtus or other nobles and in cases of theft of coal, firewood, herds, and other properties of temples and monasteries, the penalty was the confiscation of the perpetrator's entire property, including his wife and children, fine in five groups of nine livestock, etc. Stealing a property that belonged to temples and monasteries was considered as

7 The Lifan Yuan Zeli was the final version of the laws that were created for Mongolia by the Court of Colonial Affairs (Lifan Yuan), which was the administrative organ of the Qing dynasty for Mongolia and its other Inner Asian dependences. The Lifan Yuan Zeli included the administrative regulations and criminal law. For more information and bibliographic references on the Lifan Yuan Zeli see (Atwood 2004, pp. 333-34).

8 The Eighth Jebtsundamba Khutukhtu's treasury, called "The Great Treasury" (Ikh Sangiin Gazar), consisted of two divisions: the Inner Treasury (Dotood San) and the Outer Treasury (Gadaad San). The Inner Treasury concerned itself with his domestic affairs, and it also contained a section called the "Private Treasury" (Shadar San), which dealt with Jebtsundamba's personal needs, supplying his household and mansions. It was collected from the donations to Jebtsundamba Khutukhtu himself. The Outer Treasury dealt with economic and business affairs, and it contained a section called "Proliferating Treasury" (Ürjüülekh San), which was concerned with finance. It was funded from the taxation of people, and it supplied the monastic colleges of Ikh Khüree and the Ministry of Erdene Shanzodva with finances. In 1896, its income from the taxation of people was limited to 70,000 lans of silver per year. See (Nasanbaljar 1970, pp. 143-54), (Bawden 1989, p. 6, fn. 4) and (Urangua and Bayarsaikhan 2004, pp. 377,391), and Tsedev (1964).

9 The practice of imposing fines in the groups of nine animals can be traced back to some of the earliest Mongolian codes, such as the Great Yasa (Yeke Jasar) of Chinggis Khaan, Altan Khan's Law the Mongol Oirat Code Mongol, and the Mongol Code of Law. The Article 29 of the Great Yasa, reads: "The man in whose possession a stolen horse is found must return it to its owner and add nine horses of the same kind; if he is unable to pay this fine, his children must be taken instead of horses, and if he has no children, he himself will be slaughtered like a sheep." See (Riasanovsky 1965, p. 268). In the aforementioned codes, the group of nine livestock consisted of different nine animals. In the Mongolian Code of Laws, the group of nine included the following: two horses, two oxen, two cows, two three-year old male animals, and one calf. In the Khalkha Regulations, a fine in groups of five head of animals consisted of two horned-animals and three sheep, and the fine in groups of three consisted of one horned-animal and two sheep.

10 Flogging or beating was a traditional form of punishment in Mongolia. It was of three types: beating with a stick (tuivan), beating with a club (chavchirga), and flogging with a whip (tashuur). Beatings were traditionally carried out in numbers from twenty-five to one hundred.

11 According to the Khalkha Regulations, forced labor included preparing wood, carrying water, and cleaning monasteries, and this sentence had to be carried out for a period of three years. 
theft from the Three Jewels (Buddha, Dharma, and Monastic Community), and thus it called for a more severe penalty. In the earliest version of this code, in addition to fines in livestock, everyone involved in theft was subject to punishment by flogging and handcuffing. A robber was handcuffed for a year for his first offence, for two years for the second offence, and for life after the third offence. A thief was sentenced to flogging, fines in animals, circumambulations around monasteries, and prostrations, number of which depended on whether or not this was the accused first offence. The number of compulsory circumambulations of monasteries ranged from one hundred to one thousand, and the number of prostrations varied from one to ten thousand. Thus, according to the Mongol Code of Law, the theft of livestock on which a nomadic society depended for its livelihood was considered to be more serious and therefore punishable with greater penalties than the theft of various goods or domestic animals such as dogs, etc.

Later amendments to the code introduced more severe physical punishments and higher fines in livestock. The death penalty was carried out only for the first degree robbery and attacks on monasteries; and it was introduced only later, after 1746 when the amendments to the code were made under the order of the Qing emperor K'ang Hsi, who was in power in between 1661 and 1722. The earlier version of the Khalkha Regulations pointed out that sentencing a thief to death was unprofitable, since the dead thief could not pay his fine. In accordance with new amendments, if the associates in robbery were unable to pay the imposed fines, they, along with their wives and children, were sentenced to slavery. One of reasons for that was a widely spread theft of livestock, which continued until the Mongolian People's Revolution in 1925 and was carried out with exceptional swiftness by skillful professional thieves, who were difficult to catch and thus often left unpunished. While finding and returning a stolen or lost livestock was rewarded with one third of its value, its illegal appropriation by a person who found it called for punishment in the form of compensation and additional fines in animals.

The Khalkha Regulations also provided legal measures for preventing judicial abuse of power and the illegal collection of debts, which was deemed a type of theft. For instance, a debt that was forcefully and illegally collected during the day was to be considered cancelled; and such collection of debt at night was treated as a robbery. A person, who by the court's ruling became a beneficiary of the fine, was not allowed to collect it himself but only in the company of a designated court messenger (elči). Few existing references to juridical procedures in the Khalkha Regulations show that the common means for investigating a theft of livestock was tracking and that searches were conducted only when deemed necessary. ${ }^{12}$

Furthermore, the Khalkha Regulations forbade the purchasing of meat and other products for speculating purposes, conducting trade during night, and secret selling of alcohol, which were all regarded as economic exploitations of consumers and thereby as indirect modes of theft. It regulated trade through licensing in order to protect consumers from unfair prices, while also protecting the state from tax evasions.

A compilation of court cases written down in the Red Cover (Ulasan Qačartai), which documents 488 court cases decided by the Ministry of Ikh Shavi during the period of 1820-1913 and pertaining to civil and administrative crimes and related penalties, mentions altogether 488 criminal offenses. The first set of 185 court cases covers the period of 1820-1850; and the set of 303 cases covers the period of 1850-1913. The majority of recorded cases deal with either explicit or implicit acts of theft that described above. From among them, about forty cases deal with explicit cases of theft, the poor mishandling or guarding of a thief and releasing and sheltering of thieves by gatekeepers, lamas, noblemen, and commoners. The record also shows that culprits in stealing were monks and lay serfs.

12 (Riasanovsky 1965, pp. 112-26). 
For these types of crimes, a sentence ranged from one, three and five sets of the heads of livestock, to three domestic animals and yellow tea. ${ }^{13}$

\section{Discussions on Theft in The Laws and Regulations to Actually Follow (Jingki dara/u yabuqu qauli dürim)}

Many of the statues of the Khalkha Regulations continued to be applied among the personal subjects of the Eighth Bogdo, Jebtsundamba Khutukhtu during the autonomous, theocratic period, not long after the Eighth Jebtsundamba Khutukhtu became the head of the Mongolian State and Church. However, the Mongols' independence from the Qing rule and the creation of the new Bogd Khaan State called for reforms in the Mongolian legal system and for the introduction of new legal codes. The Khalkha Regulations and the earlier Qing legal code for Mongolia, the Mongolian Code of Laws (Mongrol čaraǰin- $u$ bičig), which was introduced in the seventeenth century, inevitably influenced the legal codes instituted during the autonomous period. The records of the Ministry of the All-Governing Court of the Bogd Khaan State, entitled The Records of Actions Followed by All According to Special Orders and Established by Many Ministries, Starting from the First Year of the State Supported by All, ${ }^{14}$ which contain sixty-three legislative documents, which were inaugurated by the order of the Eighth Bogdo, Jebtsundamba Khutukhtu in 1911 and applied until the spring of 1917. One of these records is the legal code entitled The Book of Law Presently Established and Implemented by the Revised Agreement of the Five Ministries, ${ }^{15}$ also known as the Laws and Regulations to Actually Follow. ${ }^{16}$ This twelve-point code was enacted from 1913 until 1918, when the Code of the Mongolian State Law Established by Order ${ }^{17}$ was prepared. Although a relatively small document, the Laws and Regulations to Actually Follow is important for understanding the history of law in independent Mongolia, since very little has been known about the Mongolian legal system of that period. The law introduced a small number of revisions to the pre-existing articles, as the new government sought to make changes in the existing law in an incremental way. Some of the revisions pertain to the death penalty and harsh sentences in certain cases of theft, which had been previously instituted by the Mongolian Code of Laws under the authority of the Qing emperor K'ang Hsi. For example, in the case of the robbery of more than twenty head of livestock, a death penalty by breaking the spine ${ }^{18}$ of the principal thief was replaced by one year long sentence of imprisonment and two years in a cangue. Similarly, a death penalty of the ringleader and his associates who stole more than thirty livestock was replaced by the sentence to hobbling in a cangue for two years, forced labor, and a hundred floggings for each of them. If the number of stolen livestock ranged from three to five, the main thief was sentenced to hobbling in a cangue for a half a year instead of to exile into one of the southern provinces in China. ${ }^{19}$ If the

13 (Bayarsaikhan and Lkhagvajav 2010, pp. 32-150).

14 Olno örgögdsönii tergüün onoos naash oloon yamnaas ailtgaad togtooson ba tusgailan zarlig buulgaj niiteer dagaj bui khergiin tovchoo devter. (Sodovsüren 1989, p. 56).

15 Tavan yam khamt niilj khuvysgan togtooj ailtgaad, odoogiin dagaj shiitgüülen bui khuuly dürmiin devter bichig.

16 Jinkhene dagaj yavakh khuuly dürem. Five Ministries include here the Ministry of All General Administration, Ministry of External Affair, Ministry of Internal Affairs, and Ministry of Defense.

17 Zarligaar togtooson Mongol Ulsyn Khuuly züiliin bichig.

18 Breaking of the spine (khövchdökh) was a traditional means of death penalty in Mongolia since the ancient time. It was based on the principle of revenge between different tribes (omog). The punishment by breaking the criminal's spine was carried out by placing a piece of wood on the back and bending the spine backward into the shape of a bow. This type of punishment was also called "bloodless punishment." The Qing code for the Mongols, the Mongolian Code of Laws (Mongol tsaazyn bichig, MongYolča of main penalties. The code also mentions the types of crimes for which this form of punishment should be executed, including the group robbery, theft of a large number of cows, horses, and camels, murder during a robbery or theft, murder of a runaway criminal who returned, hiding a criminal, and so on. The code also mentions that this type of execution had to be carried out only in autumn, when the sentenced criminal could receive a pardon by replacing the death penalty with another type of penalty. See the MongXol čaYa ̌̌ in-u bičig. (Bayarsaikhan 2004, pp. 122-24, 138-56). The word khövchdökh or khövchdön alakh, which I translate here as "breaking of the spine", also means "strangulation." In this context, it most likely refers to a breaking of the spine.

19 Forced exile into China was introduced for the first time in Mongolia by the Qing's Mongolian Code of Laws. The article 4 in the Laws and Regulations to Actually Follow mentions the following places of exile: Yunnan, Hunan, Shandun, Fujian, 
number of stolen livestock ranged between six and nine, the main thief was placed into a cangue for a year instead of being sent into exile. A replacement of sentences to death and exile for robbery and theft perhaps reflects some degree of Buddhist influence on this code. However, these reforms were not implemented in all cases. In March of 1913 the Ministry of Justice prohibited and replaced the centuries-long practice of capital punishment by breaking the spine of a criminal with execution by gun, which was carried out in the place called Sharkhad in the eastern part of the capital city. ${ }^{20}$ It also prohibited punishments by mutilation. ${ }^{21}$ However, when mentioning execution, the code itself nowhere speaks of execution by gun. As the absolute monarch, the Eighth Jebtsundamba Khutukhtu had the full authority to pardon the person sentenced to death or change the penalty. ${ }^{22}$

Another set of revisions pertinent to the topic of this paper pertains to the laws on recovering debts. One's refusal or inability to repay a debt was treated as a form of theft. The code abolished the pre-existent practice of recovering a debt from the unit (otur), smaller municipality (bag), or relatives of the person who was in substantially large debt and unable to repay it. This practice was re-evaluated as an unfair victimization of innocent clan members and was replaced by the confiscation of the property of the person in debt and by compulsory payments of monthly interest until the debt was repaid. Persons who borrowed smaller amounts of silver and were unable or unwilling to repay their debts on time or within three months after the given deadline were sentenced to certain number of beatings with a stick ${ }^{23}$ in accordance with the size of their debt and were required to pay monthly interest of one ounce of silver on the existing debt until the debt was reimbursed in full. ${ }^{24}$

It is interesting that the code makes references to monetary silver only when addressing the issues of debt and the allowance of paying fines in silver for certain offences and rewarding those who assisted in curtailing the crime. But when dealing with the direct mode of theft, the code does not contain any references to property other than livestock. A careful look at the Laws and Regulations to Actually Follow reveals that like the Khalkha Regulations, the code mirrors the nomadic and pastoral live in Mongolia, where livestock was valued more than money, even in the period when monetary transactions were widely used. This is also evidenced in the severity of punishments for the robbery of livestock. The penalty for robbery of livestock depended on the degree of involvement and on the amount of stolen livestock. The sentencing variously included deportation into exile, fine in livestock by groups of nine, flogging, compulsory labor, shackling, hobbling in a cangue, and so on. The number of stolen pieces of livestock taken into consideration in penal decision-making ranged from one to thirty. If a thief was unable to compensate his victims for the caused damages, then his district (sum), unit (otur), and clan were expected to persuade him to do so. But if he was still unable to make amends, they were required to repay it on his behalf in a consolidated way. It is obvious that this statute was to ensure two outcomes-namely, the guaranteed satisfaction of the victim of theft and an incentive for the communities to curb crime within their own districts and municipalities. The incentive for controlling theft was also given in the form of awards to those who witnessed the crime and assisted police in arresting the perpetrator.

Guandung, and so on. They are mentioned as the regions where the air is very bad. Sentencing to exile was not confined to a thief alone, but it also applied to his entire family. The same Chinese provinces are also mentioned in the earlier Mongolian Code of Laws. That code also mentions the "exile into neighborhood" and "exile into another aimag", indicating that in certain cases, the exile took place within the territories of Outer Mongolia.

20 Reportedly, execution of Buddhist monks was carried out in the same place during the prosecution of Buddhist monks on the part of People's Revolutionary Army in the 1930s. During that period, this form of an execution was called a "temporary capital punishment." Execution by gun continues to be implemented in Outer Mongolia.

21 See the introduction to the Jinkhene Dagaj Yavakh Khuuly Dürem (Urangua and Bayarsaikhan 2004, pp. 9-41). The book contains both the original Classical Mongolian version and transliteration into Cyrillic.

22 Cf. the earlier Mongolian Code of Laws, according to which, the final decision with regard to the execution of a criminal by breaking his spine or by cutting off his body has to be made by the king.

23 Beating was an ancient and common practice among Mongols. The documents from the Qing period mention a wooden stick and a club as tools used in beating; whereas, the earlier sources do not specify the tools. The code Laws and Regulations to Actually Follow mentions the use of a wooden stick (beree) in beating five times.

24 The article 5 of the Jinkhene Dagaj Yavakh Khuuly Dürem. 
The Laws and Regulations to Actually Follow provided prohibitions for a variety of fraudulent activities that were seen as implicit modes of stealing. For example, it outlawed the practice of intercepting the roads leading from the countryside to the capital city and purchasing meat and other animal products, firewood, and hay from the nomads for a low price in order to sell them for higher prices in city's markets. The code aimed to protect nomads and the residents of the capital city from this type of exploitation by regulating a trade in the following way. It required that a merchant who intended to purchase products in the countryside for the sake of resale in the capital city to obtain special permission from the related jurisdiction and tax office. Permission providing the details regarding a person in the countryside with whom the trade was conducted and the quantity of specified products had to be presented to the clerk at one of the check-stations at the entrance to the city. Toward protecting consumers in the city, the code also prohibited purchasing the entire stock of meat or other animal products, hay, and firewood in the countryside, storing it for a long period of time to make it unavailable, and then selling it for a high price. The code also aimed to protect consumers from deceptive enterprises such as the raising of the fixed prices for animal products on the part of merchants, not providing the nobles with good quality of meat, and cheating on measurements in markets. In order to prevent a fraudulent trade in the market place, the code prescribed specific types of weights and measures for different kinds of products, and it implemented surveillance of the city markets by infantry. The penalties introduced for the aforementioned violations of law were similar to those for stealing livestock. They included confiscation of the animals and other products involved in fraud, irrespective of their quantity, imprisonment up to sixty days, hobbling into a cangue, and eighty floggings.

In the Laws and Regulations to Actually Follow, a gambling with dominos (daralusu) was treated as yet another indirect mode of theft. Punitive measures for gambling included the following: (1) confiscation of the money involved in gambling; (2) sentencing of gamblers to hundred floggings and forced labor; (3) confiscation of the ger (home in the form of a felt tent) and the yard of a person who sheltered gamblers; (4) hobbling in a cangue for a half a year or for a year, and a hundred floggings of those who provided gamblers with accommodations for gambling; and (5) confiscation of horses and money belonging to those who joined the gamblers. The penalty for monks caught in gambling with cards ${ }^{25}$ and dominos varied in accordance with their ranks, and it ranged from hobbling in a cangue for forty days and hundred floggings to performing püjas for hundred days, as well as one hundred daily prostrations, and a fine in animals. Those exposing the gamblers were to be awarded fifty lans of silver.

The code provided not only incentives for the prevention of various types of theft, but it also made its prevention compulsory for all. It also aimed at ensuring the unfailing application of punitive measures for the previously mentioned crimes, pointing to the danger of the rule of law becoming ineffective and the unpunished criminals taking pride in a failure of the judiciary system, should they be left unpunished. ${ }^{26}$ Therefore, police and judiciary officials, whose task was to control crime and secure the workings of the honorable judicial system, were subject to harsh penalties if they failed in their duties. Thus, according to the code, if a policeman intentionally protected a person cheating on measurements and falsely accused an innocent person, he and his administrator had to be relieved from their jobs and sent to their native regions, where they had to be put under strict watch. Similarly, the officials who failed to properly inspect a case pertaining to gambling were sentenced to a fine of five animals each. The policeman who failed in his duty was to receive his penalty and be removed from his post. Moreover, if an interrogating official failed to bring to justice a bandit who was to be sent into exile or be executed, he was subject to the fine of nine, eighteen, or twenty-four animals and to a six-month cut in his salary. An official or a policeman who intentionally allowed a thief to escape was subject to the same penalty as the thief.

25 According to the code, gambling games with cards were introduced in Mongolia from Russia and became very popular during the theocratic period.

26 (Urangua and Bayarsaikhan 2004, p. 132). 
The code also provided statues against the illegal exploitation of thieves on the part of interrogating officials and policemen. An official who abused his position of power by appropriating the animals or other things stolen by a thief was himself considered a thief and was consequently subject to the fine of nine livestock, and each of his policemen to eighty floggings. The stolen property had to be returned to the original owner, and things that originally belonged to the thief had to be given back to him. Likewise, an interrogating official or a policeman who extorted valuable goods from a thief was to be given the same penalty as the thief.

The accountability for the occurrences of theft and other crimes in the Eighth Jebtsundamba Khutukhtu's personal estate and in the monasteries of the country's capital was also placed on the person holding the office of the Erdene Shanzodva in the Ministry of Assisting the Church and State, whose main concerns were the property and wealth of the Great Shavi, a personal estate of the Eighth Jebtsundamba Khutukhtu and his monasteries. Therefore, if someone belonging to the Great Shavi committed a crime of theft, the Erdene Shanzodva, whose duty was to keep the property of the Great Shavi safe, was subject to a salary-cut for one year. But if he was successful in preventing such crime, he was to be awarded for his good stewardship.

Large monasteries with their enormous treasuries were common targets of banditry. To protect the monasteries within the capital city from robbery and arson, the Eighth Jebtsundamba Khutukhtu approved thirty-two articles regulating the lives of monks, which were presented to him by the five ministries. According to the Laws and Regulations to Actually Follow, one of this regulations stipulated that every monastic division selected a chairman who had to be responsible for each of the ten gates. With the assistance of a disciplinarian, the chairman was to select security guards to keep night watch at the monastery's gates. Failing in this responsibility had serious repercussions. If one of the guards failed, not only he but also the chairman who selected him and the disciplinarian who approved his appointment became subject to penalty. If they were unable to pay their fines, the law required that they be removed from their positions. However, the law took into consideration the fact that these men were monks who spent all their lives in monasteries and would not know how to survive outside the monasteries' walls if sent away to tend their monasteries' herds. Therefore, instead of having to leave, a convicted disciplinarian was sentenced to performing püjas day and night and hundred daily prostrations for up to one hundred days, and a chairman was sentenced to beatings with a stick, cleaning the monastic area, and public humiliation. Like in the previously mentioned case in the Khalkha Regulations, here too we see that the religious practices that were traditionally deemed as the means of spiritual purification and merit-making became sanctioned by the state law as a form of corporeal punishment on account of being physically demanding and requiring a physical stamina. But it is quite possible that this type of punishment was also deemed as a form of mental purification of a thief.

The Laws and Regulations to Actually Follow formulated the statutes that governed and protected the life of the monastic communities and the Great Shavi. According to article 1 of this code, the official state judicators and investigators had no power to directly interrogate or penalize a fully ordained monk, a novice, or a Buddhist lay person belonging to a monastic college or to one of the monastic administrative organs. The Ministry of Erdene Shanzodva had to be informed first about the case. Similarly, if a high-ranking lama was accused of some offence, the case had to be reported first to the Khamba Nomun Khan (the "abbot dharma-rāja" of Ikh Khüree), who was authorized to issue permission for a court hearing or to avert it. In this way, the code provided a legal basis for protecting Buddhist monks from state judicial procedures and punishments, and it allowed for the implementation of religious governance (nom-un jasar) as a part of the "principle of two laws" (qoyar yosun-u sursal), the religious and secular laws. The Laws and Regulations to Actually Follow thus reflected the endorsement of this dual policy by the new theocratic government, seeking to strengthen the Mongolian state by bringing together the secular and religious segments of Mongolian society. However, this was not to happen, as new political forces in the form of the Mongolian People's Revolutionary Party (MPRP) began to emerge, which saw the power and affluence of the 
Buddhist establishment as corrupt and self-serving, and which promoted the people's revolution as kind, beneficial, and as protecting the commoners from the exploitation of the monastic nobility. Documents containing petitions and grievances of ordinary people against the nobles' corruption and misappropriation of people's funds submitted to the court was taken by the MRPR as evidence of the mistreatment of ruling classes. ${ }^{27}$ Condemning the harsh corporeal punishments imposed by the Buddhist monarchial government as ruthless and in need of urgent eradication, it sought to justify its anti-Buddhist establishment propaganda.

\section{Conclusions}

I hope that this short discussion on various aspects of theft addressed in the two mentioned legal codes opens a small window into the close interrelatedness between Buddhism and law, and between the socio-economic conditions, pastoral, nomadic culture, and a structure of Buddhist institutions and the character of the Mongolian legal system. Although the main reason for the merging of Buddhism and law in Khalkha Mongolia during the theocratic period was of a political nature, this does not diminish the significance of other factors facilitating this event. That interaction facilitated other normative orders to influence Mongolian Buddhism and its legal tradition. One example of such cases is the abduction of brides, which was a common practice among Mongols almost until the beginning of the twentieth century, and which bore no moral or social stigma. It called for a legal fine in livestock only when the groom did not give compensation to the bride's parents. The fact that the fine for not paying ransom for the abducted bride equaled that of the fine for adultery and not for theft suggests that even within the legal system, the abduction of the brides was not considered to be a form of stealing. ${ }^{28}$

Conflicts of Interest: The author declares no conflict of interest.

\section{References}

Atwood, Christopher. 2004. Encyclopedia of Mongolia and the Mongol Empire. New York: Facts on File, Inc.

Bawden, Charles R. 1989. The Modern History of Mongolia. London and New York: Kegan Paul International.

Translated by Charles R. Bawden. 1997, Tales of an Old Lama. Buddhica Britannica Series Continua; Tring: The Institute of Buddhist Studies, vol. 8 .

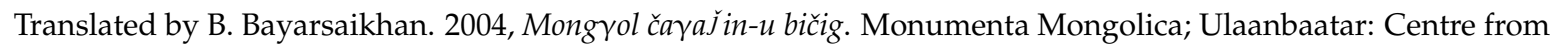
Mongol Studies, National University of Mongolia, vol. 6.

Bayarsaikhan, B., and B. Lkhagvajav. 2010. Mongolyn Shü̈̈n Taslakh Ajillagaany Tüükhen Survalj Bichigt Khiisen Shinjilgee (Ulaan Khasart) (Research on Historical and Original Mongolian Writings on Investigating Procedures, Red Cover). Ulaanbaatar: Research Center for Mongolian Law and History, Mongolian National University.

Nasanbaljar, Ts. 1970. Jibzundamba khutagtyn san. Studia Historica 8.

Translated by Sh. Rasidondug. 1975, Petitions of Grievances Submitted by the People (18th-Beginning of 20th Century). Asiatische Forschungen; Wiesbaden: Otto Harrassowitz, vol. 45.

Riasanovsky, A. Valentin. 1965. Fundamental Principles of Mongol Law. Uralic and Altaic Series; Bloomington: Indiana University, vol. 43.

27 See (Rasidondug 1975).

28 There are also instances in which non-Buddhist beliefs and customs that entered the judicial system in Khalkha Mongolia became associated with Buddhism. One of such judicial practices was a form of a trial called shakhaa, or siqay- $a$ ("oath"), which was introduced to Mongolian courts by Qing authorities. The rite was implemented in the cases in which one person would accuse another of a crime without any evidence to substantiate the accusation. To prove his innocence, the accused had to take an oath, saying, "Buddha, if you are angry [with me], take my life away", and had to crawl naked under the objects that were deemed impure and inauspicious and were hanging on a string. The impure objects included woman's underwear worn during her menstrual period, shoe soles, discarded bones, rope, hobble, dogs' excrement, dried head of a camel, and so on. If the body of the accused did not touch these objects while crawling under them, he was proclaimed innocent. 
Sodovsüren, B. 1989. Khovysgalyn ömnökh Mongolyn tör ba Khuuly Tsaaz: 1911-1920. Ulaanbaatar: Publisher unknown. Tsedev, D. 1964. Ikh Shavi (Great Shavi). Ulaanbaatar: Publisher Unknown.

Translated by Kh. J. Urangua, and Kh. B. Bayarsaikhan. 2004, Jinkhene Dagaj Yavakh Khuuly Dürem. Ulaanbaatar: School of Law, Institute of Historical Studies, National University of Mongolia. 